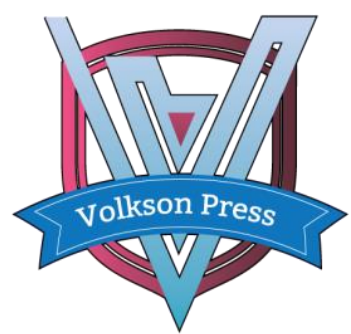

Contents List available at VOLKSON PRESS

Economics \& Management Innovations(EMI)

DOI : http://doi.org/10.26480/icemi.02.2018.52.55

ISBN: 978-1-948012-14-0

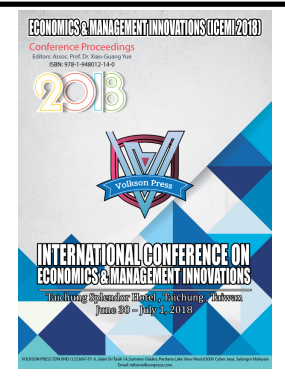

\title{
AN EMPIRICAL RESEARCH ON GREEN PRODUCTION EVALUATION
}

\author{
Sang-Bing Tsai \\ Zhongshan Institute, University of Electronic Science and Technology of China, Guangdong 528402, China. \\ *Corresponding Author E-mail: sangbing@hotmail.com
}

This is an open access article distributed under the Creative Commons Attribution License, which permits unrestricted use, distribution, and reproduction in any medium, provided the original work is properly cited.

\section{ARTICLE DETAILS}

\section{Article History:}

Received 26 June 2018

Accepted 2 July 2018

Available online 1 August 2018

\begin{abstract}
Green production, which is a relative and dynamic concept, mainly covers the three aspects of process, product, and service; therefore, green production itself is a process of continuous improvement. With the advancements of technology and economic development, the connotation of green production continues to update and progress. Green production mainly refers to minimizing the environmental hazards of waste in the manufacturing process, in order that resources and raw materials can be used most effectively. Green production emphasizes pollution prevention in industrial manufacturing processes and includes all possible impacts on the ecological environment. How to use scientific and quantitative methods to explore the evaluation index of green production and evaluate the performance of green production is the focus of this study. This study uses the Importance-Performance Analysis method to determine the green production evaluation index and analyze the competitive strategy of the industry, and then, uses them as the basis for the improvement of the case company.
\end{abstract}

\section{KEYWORDS}

Green production, evaluation index, Importance-Performance Analysis Model, Competitive Strategy.

\section{INTRODUCTION}

Due to the increasingly strict corporate environmental challenges, advanced countries, such as Europe and the United States, regard pollution prevention and resource conservation as the development direction of national environmental policies. They have changed the command control model with government as the main body and environmental protection work based on end-of-pipe pollution control of the past into the partnership between government and the business community to jointly promote pollution prevention and control and turn environmental management into systematic work. The systematic approach of management, improvement, measurement, and communication requires end-of-pipe treatments to meet emission and regulation standards, which go beyond the scope of pollution reduction and pollution prevention, to become a comprehensive method of corporate green environmental management. Under the "environmental concept", the industry designs, plans, and produces low-pollution products, that is, it adds "environmental management" works into the current functions of enterprise management $[1,2]$.

In 1989, UNEN began to explain the concept and characteristics of Green Production or Clean Production to the outside world, which clearly defined its scope and application. UNEP believes that if enterprises only deal with pollutants with end-of-pipe treatment, processing costs cannot be reduced, and cost-effectiveness cannot be improved. If enterprises can manage to reduce the generation and disposal of waste, it may relatively increase the efficiency of production and reduce their costs. Since 1990, European and American business communities have implemented Cleaner Production Technology after achieving good results in waste reduction [3].

UNEP made a clear definition of green production in 1997, as follows: "Green production is the continuous application of an integrated preventive environmental strategy applied to processes, products, and services to increase eco-efficiency and reduce risks to humans and the environment." In general, green production mainly covers the three aspects of process, product, and service: 1) Process: Use low-hazard raw materials combined with production procedures of less waste and efficient production equipment to reduce various risk factors and harmful intermediate products in the production process and reduce the amount and toxicity of waste to maximize the efficient use of energy resources. 2) Product: Minimize the adverse effects and hazards on the ecological environment by the product itself and during the use as far as possible. When the product loses its function, it should be easy to recycle, regenerate, and reuse. At the same time, we must also take the entire life cycle of the product into consideration, taking the necessary measures in all stages of product development, product planning, product design, raw material processing, product output, product use and end-of-life disposal to minimize the resource and energy consumption of the product life cycle. 3) Service: Incorporate environmental elements into the design and services provided, and reduce the environmental damage caused by the provision of services.

How to use scientific and quantitative methods to explore the evaluation index of green production and the performance of green production is the focus of this study. This study expects to determine the green production evaluation index and analyze the competitive strategy of the industry to provide improvement for the industry.

\subsection{Literature Review - Evaluation Index for Green Production}

Green production is a relative and dynamic concept; therefore, green production itself is a process of continuous improvement. With the advancement of technology and economic development, the connotation of green production continues to update and progress. Enterprises that produce green products should introduce the concepts of green production and clean production and transform their original high-energy and high-pollution production equipment. In the design process of green products, the extension and reuse of green product functions should be fully considered to save raw materials and reduce waste [4]. 
In 1995, the Industrial Development Bureau commissioned the Industrial Technology Research Institute to establish the Center of Cleaner Production to determine the waste generation rate (WGR), energy consumption index (ECI), hazard index (HZI), and other evaluation indices for evaluating green production. In 1997, it established the clean production index for industries, including the leather industry, food processing industry, dyeing and finishing industry, electronic petrochemical industry, and dye industry, and set the pollution load per unit raw material, pollution load per unit production, pollution load per unit output value, energy consumption index, waste generation index, hazard index, etc [5].

According to the research of Despeisse, the green production index can be roughly classified into three types according to their nature [6]:

1) Macro indices: Such indices can be used to understand the commitment of the company or manager to the environment; for example, whether there is a reduction plan and whether it is verified by ISO 14001, as well as the number and amount of environmental fines each year. Such indices are qualitative in nature and are usually relative or unable to provide specific data validation, thus, they should not be exclusively used.

2) Microscopic indices: Such indices must be calculated or analyzed via data before the index values can be obtained; for example, the waste generation rate per unit of product must define the waste category in detail, such as general industrial wastes or hazardous industrial wastes. These indices provide a quantitative index that can be used to show the cleanliness performance of the plant itself, as well as used to compare the cleanliness of the same product with different processes or the cleanliness of the same product produced by different plants.

3) Environmental design indices: Such indices are usually obtained from the analysis result of product life cycle; for example, through analysis of the product life cycle, the Eco-indicator gives the index value of the material according to its impact on the environment. This index allows product designers to select materials, energy, and raw materials that have the least impact or load on the environment at the beginning of the design.

Based on the above discussion, we can understand that there are two main goals for green production: 1) Reduce the generation and discharge of waste in the production process to achieve rational use of resources and reduce the environmental hazards of the entire production activity. 2) Through the effective use of materials and energy resources, the reuse of energy resources has achieved the rational use of resources. The green production evaluation index mainly covers the green processes and pollutant treatments according to the manufacturing aspect, the material uses, and energy consumption of the resource saving aspect, the green design, product recycling of the product design aspect, the environmental protection and social responsibility of the green management aspect, etc [7].

\section{METHOD}

The Importance-Performance Analysis (IPA) was first proposed by Martilla and James for the basic architecture and practical application [812]. IPA plots the importance and performance average scores of an attribute in a two-dimensional graph, where the vertical axis represents importance and the horizontal axis represents performance, as shown in Figure 1 [13-19].

The four quadrants in the IPA method each have their own definition:

(1) Keep up the good work: Indicates that customers attach great importance to the attributes of the area and are satisfied with the performance of the company. Therefore, this attribute falls in the quadrant of "Keep up the good work".

(2) Concentrate here: Indicates that customers attach great importance to the attributes of the area but are not satisfied with the performance of the company. Therefore, this attribute falls in the quadrant of "Concentrate here".

(3) Low priority: Indicates that customers attach little importance to the attributes of the area and are not satisfied with the performance of the company. Therefore, this attribute falls in the quadrant of "Low priority".

(4) Possible overkill: Indicates that customers attach little importance to the attributes of the area but are satisfied with the performance of the company. Therefore, this attribute falls in the quadrant of "Possible overkill".

Through the division of different regions, managers can make the most effective use of limited resources and provide priority ranking for improvements to enhance satisfaction [20-25]. The IPA analysis method is a method that can easily show the quality and improvement of attributes, and it has been widely cited by many scholars in other fields as a tool for analyzing attributes to improve priority ranking and satisfy customer needs [26-28].

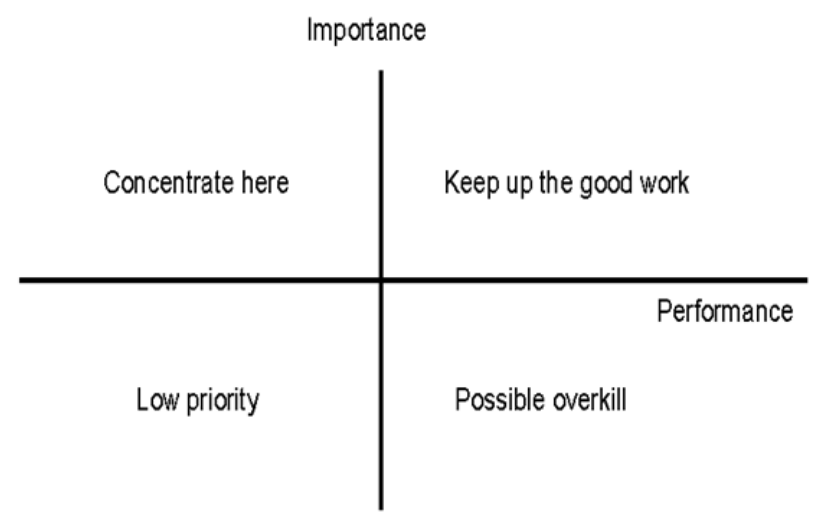

Figure 1: Importance-Performance Analysis

\section{RESEARCH RESULTS AND DISCUSSION}

Company X is in the top three printed circuit board companies in Taiwan. This study takes Company $\mathrm{X}$ as the object of case study to evaluate its green production performance, which is used as the basis for improvements to the case company. This questionnaire uses a Likert seven-point scale, which has a total of 12 questions. The questionnaire surveyed a total of 30 Taiwanese experts regarding printed circuit boards, including 12 professors, 15 senior executives of printed circuit board companies, and 5 government officials. A total of 32 formal questionnaires were issued, 32 valid questionnaires were responded, for an effective respond rate of $100 \%$.

In this study, the importance mean value (5.84) and the performance mean value (5.68) in the questionnaire are used as the standard coordinates to determine whether each attribute performs well or poorly. Please see Table 1 for details. According to the results of IPA analysis, Company X belongs to "Keep up the good work" in 4 criteria (3) waste ratio per unit revenue, (5) air and wastewater discharge compliance rate, (6) environmental pollution violations, (12) degree of product recovery, which are advantages of Company $\mathrm{X}$, and it must maintain this rating to maintain its competitive performance and help the company achieve better green production performance.

Company X has competitive disadvantages in four criteria (1) power consumption rate per unit revenue, (8) utilization rate of renewable wastewater, (10) green product design, (11) green procurement ratio of main raw materials), and they belong to "Concentrate here". Company $\mathrm{X}$ must pool resources to enhance the competitiveness of these four criteria, in order to reverse the disadvantages and improve its environmental performance. In addition, the two criteria of (2) water consumption rate per unit revenue and (9) utilization rate of regenerative heat energy have high importance and low performance, thus, they belong to "Low priority". Company X does not perform well; however, as these criteria have low importance, it can be placed in the final position, meaning they may be improved when the company has extra resources.

Finally, the two criteria of (4) proportion of the environmental protection equipment accounted for the revenue and (7) utilization rate of main raw 
material have low importance and high performance, thus, they belong to "Possible overkill". While Company X performs well, they cannot bring better green production performance to the company, thus, it should consider transferring company resources to other competitive attributes. Please see Table 1 for details.

Table 1: The Importance-Performance Analysis of Green Production Evaluation Index

\begin{tabular}{|l|l|l|l|l|}
\hline Question & Criteria & Importance & Performance & Competitive Strategy \\
\hline 1 & $\begin{array}{l}\text { Power consumption rate per unit } \\
\text { revenue }\end{array}$ & 5.9 & 5.5 & Concentrate here \\
\hline 2 & $\begin{array}{l}\text { Water consumption rate per unit } \\
\text { revenue }\end{array}$ & 5.5 & 5.4 & Low priority \\
\hline 3 & Waste ratio per unit revenue & 6.1 & 5.9 & Keep up the good work \\
\hline 4 & $\begin{array}{l}\text { Proportion of the environmental } \\
\text { protection equipment accounted } \\
\text { for the revenue }\end{array}$ & 5.7 & 5.8 & Possible overkill \\
\hline 5 & $\begin{array}{l}\text { Air and wastewater discharge } \\
\text { compliance rate }\end{array}$ & 6.3 & 6.0 & Keep up the good work \\
\hline 6 & $\begin{array}{l}\text { Environmental pollution } \\
\text { violations }\end{array}$ & 6.1 & 5.9 & Keep up the good work \\
Utilization rate of main raw & 5.3 & 6.1 & Possible overkill \\
\hline 7 & $\begin{array}{l}\text { Utilization rate of renewable } \\
\text { wastewater }\end{array}$ & 5.9 & 5.2 & Concentrate here \\
\hline 9 & $\begin{array}{l}\text { Utilization rate of regenerative } \\
\text { heat energy }\end{array}$ & 5.3 & 5.5 & Low priority \\
\hline 10 & Green product design & 6.0 & 5.5 & Concentrate here \\
\hline 11 & $\begin{array}{l}\text { Green procurement ratio of main } \\
\text { raw materials }\end{array}$ & 6.1 & 5.4 & Keep up the good work \\
\hline 12 & Degree of product recovery & 5.9 & 5.9 & 5.68 \\
\hline Average & & & & \\
\hline
\end{tabular}

\section{CONCLUSION}

There are many kinds of waste waters, waste liquids, and wastes generated in the production process of printed circuit boards. In addition to containing a variety of organic pollution, it also contains a large amount of heavy metals, such as copper, lead, and nickel, and the pollution intensity is significant. If pollution prevention works are not done well, it may cause serious environmental pollution. How to reduce environmental pollution in the production process and promote green production in industry has always been a topic of great concern to enterprises and administrative environmental protection units.

This study used the IPA method to analyze the green production performance and competitive strategy of the case company, which was used as the basis for the improvement of the case company. The research results show that: Company X belongs to "Keep up the good work" in the four criteria of (3) (5) (6) and (12). These are the advantages of Company $\mathrm{X}$, meaning it must maintain them to maintain its green production performance and help the company achieve better environmental performance. However, Company X has competitive disadvantages in the four criteria of (1) (8) (10) and (11), which belongs to "Concentrate here". Company X must pool resources to enhance the competitiveness of these four criteria, in order to reverse the disadvantages and improve its green production performance.

\section{ACKNOWLEDGMENTS}

Zhongshan City Science and Technology Bureau Project (No. 2017B1015).

\section{REFERENCES}

[1] Chiang, S.Y., Wei, C.C., Chiang, T.H., Chen, W.L. 2011. How can electronics industries become green manufacturers in Taiwan and Japan. Clean Technologies and Environmental Policy, 13 (1), 37-47.

[2] Cheng, Y., Tao, F., Liu, Y., Zhao, D., Zhang, L., Xu, L. 2013. Energy-aware resource service scheduling based on utility evaluation in cloud manufacturing system. Proceedings of the Institution of Mechanical Engineers, Part B: Journal of Engineering Manufacture, 227 (12), 1901-
1915.

[3] Tsireme, A.I., Nikolaou, E.I., Georgantzis, N., Tsagarakis, K.P. 2012. The influence of environmental policy on the decisions of managers to adopt G-SCM practices. Clean Technologies and Environmental Policy, 14 (5), 953-964.

[4] Winn, S.F., Roome, N.J. 1993. R \& D management response to the environment current theory and implications to practice and research. $\mathrm{R}$ \& D Management Review, 23 (2), 147-160.

[5] Oliver, H., Abhishek, T. 2013. Environmental appraisal of green production systems: Challenges faced by small companies using life cycle assessment. International Journal of Product Research, 51 (19), 58845896.

[6] Despeisse, M., Ball, P.D., Evans, S., Levers, A. 2012. Industrial ecology at factory level: a prototype methodology. Proceedings of the Institution of Mechanical Engineers. Part B: Journal of Engineering Manufacture, 226 (10), 1648-1664.

[7] Lam, T.I., Chan, H.W., Chau, C.K., Poon, C.S. 2011. Environmental management system vs green specifications: How do they complement each other in the construction industry. Journal of Environmental Management, 92, 788-795.

[8] Martilla, J.A., James, J.C. 1977. Importance-Performance Analysis. Journal of Marketing, 41 (1), 77-79.

[9] Tsai, S.B., Wei, Y.M., Chen, K.Y., Xu, T. 2016. Evaluating Green Suppliers from Green Environmental Perspective. Environment and Planning BPlanning \& Design, 43 (5), 941-959.

[10] Tsai, S.B. 2016. Using Grey Models for Forecasting China's Growth Trends in Renewable Energy Consumption. Clean Technologies and Environmental Policy, 18, 563-571.

[11] Guo, J.J., Tsai, S.B. 2015. Discussing and Evaluating Green Supply Chain Suppliers: A Case Study of the Printed Circuit Board Industry in China. South African Journal of Industrial Engineering, 26 (2), 56-67.

[12] Tsai, S.B., Huang, C.Y., Wang, C.K., Chen, Q. 2016. Using a Mixed Model 
to Evaluate Job Satisfaction in High-Tech Industries. Plos One, 11 (5), e0154071. doi: 10.1371/journal.pone.0154071

[13] Lee, Y.C., Chu, W.H., Chen, Q., Tsai, S.B. 2016. Integrating DEMATEL Model and Failure Mode and Effects Analysis to Determine the Priority in Solving Production Problems. Advances in Mechanical Engineering, 8 (4), $1-12$.

[14] Tsai, S.B., Xue, Y., Zhang, J., Chen, Q. 2016. Models for Forecasting Growth Trends in Renewable Energy. Renewable \& Sustainable Energy Reviews, DOI: 10.1016/j.rser.2016.06.001.

[15] Qu, Q., Chen, K.Y., Wei, Y.M. 2015. Using Hybrid Model to Evaluate Performance of Innovation and Technology Professionals in Marine Logistics Industry Mathematical Problems in Engineering, Article ID 361275, 8 pages, http://dx.doi.org/10.1155/2015/361275.

[16] Zhou, J., Wang, Q., Tsai, S.B. 2016. How to Evaluate the Job Satisfaction of Development Personnel. IEEE Transactions on Systems Man Cybernetics-Systems, 10.1109/TSMC.2016.2519860.

[17] Su, J.M., Lee, S.C., Tsai, S.B., Lu, T.L. 2016. A comprehensive survey of the relationship between self - efficacy and performance for the governmental auditors. Springer Plus, 5, 508. DOI 10.1186/s40064-0162104-x.

[18] Tsai, S.B., Lee, Y.C., Guo, J.J. 2014. Using modified grey forecasting models to forecast the growth trends of green materials. Proceedings of the Institution of Mechanical Engineers. Part B: Journal of Engineering Manufacture, 228 (6), 931-940.

[19] Chen, H.M., Wu, C.H., Tsai, S.B., Yu, J. 2016. Exploring key factors in online shopping with a hybrid model. Springer Plus, 5, 20-46. DOI 10.1186/s40064-016-3746-4.

[20] Deng, X.Y., Hu, Y., Deng, Y., Mahadevan, S. 2014. Environmental impact assessment impact assessment based on numbers. Expert Systems with
Applications, 41 (2), 635-643.

[21] Wang, J., Yang, J., Chen, Q., Tsai, S.B. 2016. Collaborative Production Structure of Knowledge-sharing Behavior in Internet Communities. Mobile Information Systems, Article ID 8269474, 9 pages, http://dx.doi.org/10.1155/2016/8269474.

[22] Wang, J., Yang, J., Chen, Q., Tsai, S.B. 2016. Creating the Sustainable Conditions for Knowledge Information Sharing in Virtual Community. Springer Plus, 5, 10-19. DOI 10.1186/s40064-016-2702-7.

[23] Lee, Y.C., Wang, Y.C., Chien, C.H., Wu, C.H. 2016. Applying Revised Gap Analysis Model in Measuring Hotel Service Quality. Springer Plus, 5, 11-91. DOI 10.1186/s40064-016-2823-z.

[24] Lee, Y.C., Wang, Y.C., Lu, S.C., Hsieh, Y.F. 2016. An Empirical Research on Customer Satisfaction Study: A Consideration of Different Levels of Performance. Springer Plus, 5, 1577, DOI 10.1186/s40064-016-3208-z.

[25] Chin, T., Tsai, S.B., Fang, K., Zhu, W. 2016. EO-Performance relationships in Reverse Internationalization by Chinese Global Startup OEMs: Social Networks and Strategic Flexibility. PLoS ONE, 11 (9), e0162175. doi: 10.1371/journal.pone.0162175.

[26] Lee, S.C., Su, J.M., Tsai, S.B., Lu, T.L. 2016. A comprehensive survey of government auditors' self - efficacy and professional Development for improving audit quality. Springer Plus, 5, 1263, DOI 10.1186/s40064-0162903-0.

[27] Chen, H.M., Wu, C.H., Tsai, S.B., Yu, J. 2016. Exploring key factors in online shopping with a hybrid model. Springer Plus, 5, 20-46. DOI 10.1186/s40064-016-3746-4.

[28] Ge, B., Jiang, D., Gao, Y., Tsai, S.B. 2016. The Influence of Legitimacy on a Proactive Green Orientation and Green Performance: A Study Based on Transitional Economy Scenarios in China. Sustainability, 8, 1344, 1-20. doi:10.3390/su8121344. 